DOI:10.18276/sip.2016.45/2-03

\title{
Iwona Foryś*
}

Uniwersytet Szczeciński

\section{INDEKSY CEN NIERUCHOMOŚCI DLA MAŁYCH OBSZARÓW}

\section{Streszczenie}

W artykule podjęto tematykę budowy cen indeksów mieszkań, uwzględniając koncepcję R. Shillera. Wskazuje on na problem jednorodności danych wykorzystywanych do budowy indeksów. Dokonano przeglądu metod i doświadczeń wybranych państw Unii Europejskiej konstruujących indeksy cen mieszkań. Na tym tle dokonano oceny podjętych działań w Polsce. Na przykładzie wybranego lokalnego rynku i zdefiniowanego typowego mieszkania weryfikowano hipotezę dotyczącą jakości indeksów cen mieszkań na rynku lokalnym i indeksu regionalnego.

Słowa kluczowe: wycena nieruchomości, indeksy cen mieszkań, rynek nieruchomości

\section{Wstęp}

Koncepcja budowy indeksów cen mieszkań ma na świecie długa historię, jednak nie straciła na aktualności. Liczne prace wskazują na to, iż dyskusja na temat ich wyznaczania jest ciągle ożywiona, a przyjmowana metodologia budzi zastrzeżenia, skłaniając autorów do dalszych badań (Fleming, Nellis, 1994; Bourassa, Hoesli, Sun, 2006; Meese, Wallace, 1997). Między innymi R. Shiller (laureat Nagrody Nobla z 2013 r.) wskazuje na problem jednorodności danych wykorzystywanych do budowy omawianych indeksów cen (http:/www.spindices.com/index-family/real-estate/sp-

\footnotetext{
* Adres e-mail: forys@wneiz.pl.
} 
-case-shiller). Sugeruje dwuetapowość budowy indeksów: w kroku pierwszym konstrukcję cen domów na jednorodnych obszarach, na przykład z uwagi na poziom urbanizacji, liczbę ludności, w następnym kroku na ich podstawie wyznaczanie zagregowanych indeksów cen dla większych obszarów. Fundamentem tej koncepcji jest jednak zdefiniowanie typowej nieruchomości lub jednorodnego lokalnego rynku, który stanowi stały punkt odniesienia dla ustalania wag stosowanych w wielu metodach wyznaczania indeksów cen w kolejnych okresach badania.

Celem prezentowanego artykułu jest wyznaczenie indeksu cen wybranego rodzaju nieruchomości dla jednorodnego obszaru miasta. Do konstrukcji indeksu wykorzystano cechy wybranego rodzaju nieruchomości. Uzyskane wyniki porównano z indeksem cen wyznaczanym dla większego, a zarazem niejednorodnego z uwagi na wcześniej przyjęte kryteria obszaru miasta.

Podjęta w opracowaniu dyskusja jest bardzo aktualna z uwagi na cykl koniunkturalny na rynku nieruchomości i decyzje, które podejmują inwestorzy na tym rynku, kierując się tendencjami wynikającymi ze zmian indeksów cen. Również na poziomie Unii Europejskiej trwają ożywione dyskusje na temat włączenia indeksu cen mieszkań zajmowanych przez właścicieli do zharmonizowanego wskaźnika cen konsumpcyjnych. Zauważono również ważną rolę, jaką pełnią ceny domów (mieszkań) w zbiorze europejskich wskaźników gospodarczych stanowiących podstawę oceny kondycji gospodarczej państw członkowskich (Handbook on Residential Property..., 2013, s. 11). Jednocześnie jest to ważki problem na rynku polskim, na którym omawiane indeksy cen z mocy ustawy o gospodarce nieruchomościami mają być wyznaczane przez Główny Urząd Statystyczny, a jak dotąd nie zostały opublikowane. Stąd uzyskane w badaniu wyniki dla rynku mieszkaniowego są przyczynkiem do dalszych badań na innych rynkach lokalnych oraz dla innych rodzajów nieruchomości.

\section{Metodyka wyznaczania indeksów cen nieruchomości}

Monitorowanie cen nieruchomości jest bardzo ważne, szczególnie w okresie zmian koniunkturalnych. W skali makro jest to jednak utrudnione z uwagi na mnogość metod wyznaczania indeksów cen i ich modyfikacji na poziomie poszczególnych krajów. Taki stan nie pozwala na porównywanie indeksów wyznaczanych przez poszczególne kraje, a wewnątrz nich różnorodne instytucje. Wspomniana niejednolitość metodologii wyznaczania indeksów cen nieruchomości wynika przede wszystkim z cech rynku nieruchomości (Foryś, 2012; Batóg, Foryś, 2013). Z nie- 
jednorodności tego rynku wynika, że indeksy powinny być wyznaczane dla poszczególnych rynków rodzajowych, a także na rynkach lokalnych i małych obszarach. Dodatkowo istotne jest, czy indeks jest wyznaczany z cen ofertowych, czy cen transakcyjnych (Wood, 2005). Rozbieżność w obu cenach jest zależna zarówno od cyklu koniunkturalnego, jak i od lokalnego otoczenia rynku nieruchomości. Nieruchomości i ich cechy wykorzystywane do wyznaczania indeksów cen nie są heterogeniczne (Foryś, 2010). Kryterium podobieństwa jest nieprecyzyjne, przyjęte cechy są $\mathrm{w}$ wielu przypadkach uzależnione od celu, do jakiego służą pozyskane informacje. W przypadku cech jakościowych pojawia się dodatkowo problem arbitralnego ustalania zarówno kategorii cech, jak i ich gradacji na najsłabszych skalach pomiaru. Dodatkowo cechy te zmieniają się w czasie wraz ze zmianą preferencji nabywców na rynku. Mogą one być również wynikiem przeprowadzonych w okresie badania remontów czy ulepszeń, które wpływają na cenę transakcyjną, a jednocześnie nie są odnotowane w źródłach danych, z których informacje czerpie podmiot konstruujący indeksy cen. Nie ma więc ostatecznego i stabilnego w czasie zestawu cech dla poszczególnych rodzajów nieruchomości, które mogą być wykorzystane w konstrukcji ponadczasowych indeksów cen.

Kolejnym problemem metodologicznym jest obserwacja zmiany cen i cech danej nieruchomości w czasie. Informacje, które są dostępne na rynku, są opóźnione nawet o kilka miesięcy. Dodatkowo badacze podejmujący próby konstruowania indeksów cen na polskim rynku nieruchomości zwracają uwagę na ograniczony zasób informacji o przeprowadzonych transakcjach (Trojanek, 2010), który powoduje zawężanie zbioru cech wykorzystywanych do modeli jako zmienne objaśniające.

W konsekwencji współistnieje wiele metod i różnych wskaźników cen nieruchomości (Calhoum, 1996) często wyznaczanych na podstawie własnych i ograniczonych zbiorów danych będących w posiadaniu instytucji konstruującej dany wskaźnik. Różnią się one przede wszystkim podejściem do sprowadzania cech badanych obiektów do porównywalności w celu zniwelowania ograniczeń, jakie niesie ich zmiana wraz z upływem czasu i zmianami preferencji nabywców. Można wskazać na dwie główne grupy indeksów:

a) proste nieuwzględniające cech nieruchomości oraz czasu (bazują na miarach średnich);

b) złożone, które w różnym zakresie uwzględniają wskazane elementy.

Wśród metod złożonych wyróżnia się: mix-adjustement (skorygowanych cen), regresję hedoniczną, regresję powtórnej sprzedaży oraz kompilację tych metod, na przykład metodę hybrydową (Shiller, 1991; Calhoun, 1996; Wood, 2005). Metody 
proste, do których można zaliczyć klasyczne indeksy cen (Foryś 2013), cechuje łatwość obliczeń, ale nie uwzględniają one zmian jakościowych i strukturalnych nieruchomości (podobnie jak klasyczne metody indeksów cen towarów konsumpcyjnych). W pewnym zakresie niedogodność tę niweluje metoda mix-adjustement, czyli metoda skorygowanych (ważonych) cen. W pierwszym etapie badaną zbiorowość dzieli się na jednorodne grupy z uwagi na wybrane kryteria, przy czym cechy tych nieruchomości są mierzone najczęściej na skalach słabych. W kolejnym etapie dla każdej grupy wyznaczana jest cena przeciętna, która ważona jest udziałem (liczebnością) danej grupy w badanej zbiorowości. Punktem odniesienia dla indeksu jest okres bazowy. Wartości indeksu wyznacza się jako średnią ważoną ceny nieruchomości w okresie, którego indeks dotyczy. Na jakość indeksu wpływają: zestaw cech wyróżniających grupę, rozkłady cech w grupie i jej liczebność, a w dłuższej perspektywie także stabilność preferencji nabywców nieruchomości.

Zaletą kolejnej metody (regresji hedonicznej) jest większa dokładność i uwzględnienie cech nieruchomości, które jednak nie zmieniają się w czasie zgodnie z zachowaniami konsumentów. Wady metody wynikają z niedoskonałości modeli regresji (koincydencja, regresja pozorna itp.). W metodzie regresji hedonicznej zmienną objaśnianą jest cena nieruchomości, natomiast zmiennymi objaśniającymi cechy nieruchomości. Oszacowane współczynniki modeli regresji dla badanych lat są wykorzystywane do wyznaczenia indeksu w odniesieniu do okresu początkowego. Można w tym celu wykorzystać również jeden model regresji uwzględniający binarną zmienną czasu. Jednak jeśli cechy nieruchomości nieuwzględnione w modelu były istotniejsze w niektórych fazach cyklu koniunkturalnego, to amplituda wahań indeksu w tym okresie może być w sposób nieuzasadniony zaniżona lub zawyżona. W zależności od sposobu wykorzystania (bezpośredniego lub pośredniego) modelu regresji do budowy indeksu można dodatkowo wyróżnić różne metody regresji hedonicznej (Widłak, 2010).

Metoda regresji hedonicznej podobnie jak metoda mix-adjustement wymaga obszernego zbioru wiarygodnych danych. Dysponując ograniczonym zbiorem informacji (wystarczą ceny sprzedaży w dwóch punktach czasu, tzw. powtórna sprzedaż tej samej nieruchomości), pozwala na wykorzystanie metody powtórnej sprzedaży. Mankamentem tego podejścia jest założenie o niezmienności cech nieruchomości istotnych dla stron umowy w okresie między dwiema transakcjami oraz uwzględnienie ograniczonej liczby ogółu transakcji rynkowych, która nie musi być reprezentatywna dla całego rynku. 
Żadna z wymienionych metod nie jest pozbawiona wad, stąd założenie o poszukiwaniu lokalnych rynków jednorodnych z uwagi na przyjęty zestaw cech tego rynku i jego otoczenia stwarza szanse na wyznaczenie dokładniejszych indeksów cen nieruchomości.

\section{Indeksy cen nieruchomości w Polsce}

Konieczność wyznaczania wskaźników zmian cen nieruchomości w Polsce wynika z ustawy o gospodarce nieruchomościami (Dz.U. 2015, poz. 782, z późn. zm.). Artykuł $5 \mathrm{w}$ brzmieniu: „Waloryzacji kwot należnych z tytułów określonych w ustawie dokonuje się przy zastosowaniu wskaźników zmian cen nieruchomości ogłaszanych przez Prezesa Głównego Urzędu Statystycznego, w drodze obwieszczeń, w Dzienniku Urzędowym Rzeczypospolitej Polskiej «Monitor Polski»»" wskazuje instytucję, na którą ustawodawca nakłada obowiązek wyznaczania indeksu, a która dotychczas tego obowiązku nie zrealizowała. W państwach, w których wyznaczane są indeksy lub wskaźniki zmian cen nieruchomości, dotyczą one przede wszystkim nieruchomości mieszkalnych. Wynika to z kilku przesłanek, z których najważniejszą jest znaczący obrót mieszkaniami na rynku. Ponieważ transakcje te są przede wszystkim finansowane kredytami, stąd rośnie zainteresowanie sektora bankowego zmianami cen nieruchomości, które zabezpieczają udzielane przez nie kredyty długoterminowe (Łaszek, Widłak, 2008). Od III kwartału 2006 roku Narodowy Bank Polski (NBP) prowadzi monitoring rynku mieszkaniowego (pierwotnego i wtórnego) w największych miastach, publikując kwartalne średnie jednostkowe ceny ofertowe i transakcyjne mieszkań oraz indeks hedoniczny dla rynku wtórnego'. Baza cen nieruchomości mieszkaniowych $(\mathrm{BaRN})$ prowadzona przez NBP powstaje dzięki informacjom dobrowolnie przekazywanym przez biura pośrednictwa w obrocie nieruchomościami, deweloperów oraz danym gromadzonym przez oddziały okręgowe NBP (www.nbp.pl/publikacje/rynek_nieruchomosci/ceny_mieszkan.xls). Badanie dotyczy 16 miast wojewódzkich (transakcje zawierane w granicach administracyjnych miast) oraz Gdyni, w których odbywa się najwięcej transakcji mieszkaniowych. Dla wskazania zasadności ograniczania się do jednorodnych lokalnych rynków wykorzystano w artykule indeks hedoniczny konstruowany na bazie cen mieszkań gro-

\footnotetext{
Indeks hedoniczny cen mieszkań odzwierciedla „czystą” cenę, tj. wynikającą z innych czynników niż różnice w jakości mieszkań. Analizowana jest zawsze cena wystandaryzowanego mieszkania przeciętnego dla danego rynku, stworzonego na podstawie modelu ekonometrycznego (Widłak, 2010).
} 
madzonych przez NBP. Wyznaczony kwartalny indeks hedoniczny (od III kwartału 2007 r.) odzwierciedla zmianę cen oczyszczoną ze zmian jakościowych, uwzględnia zmiany jakości mieszkań badanej próby w każdym kwartale (Widłak, 2010). Na rysunku 1 przedstawiono kształtowanie się indeksu hedonicznego NBP wyznaczonego dla Szczecina w latach 2007-2012.

Rysunek 1. Indeks hedoniczny mieszkań na rynku wtórnym w Szczecinie w latach 2007-2012

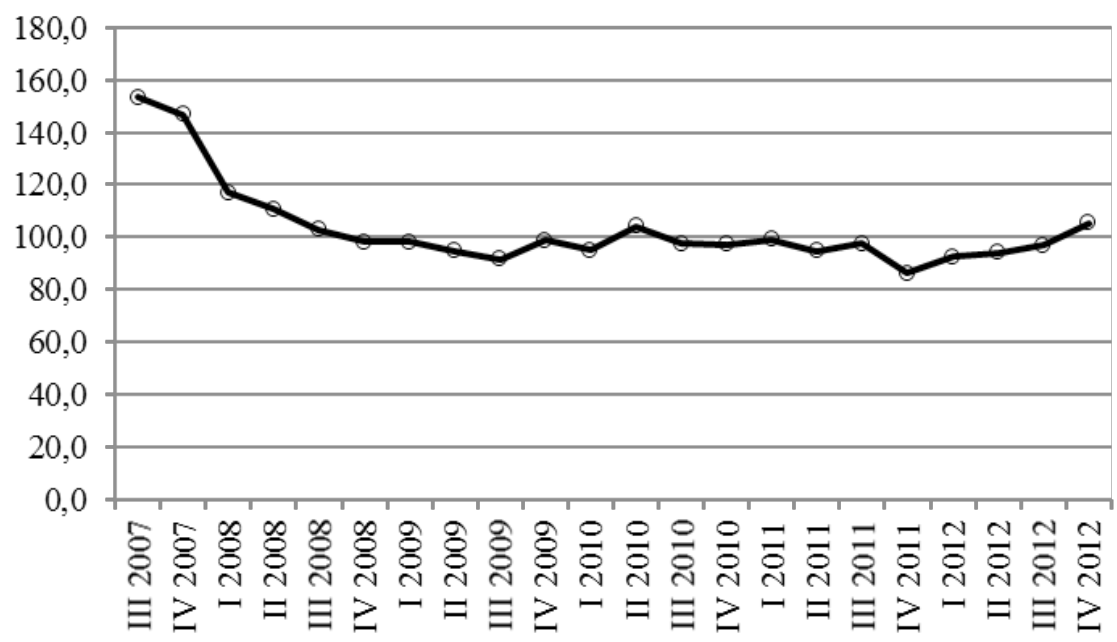

Źródło: opracowanie własne na podstawie danych NBP.

Prezentowany indeks ukazuje dynamikę cen jednostkowych mieszkań w Szczecinie w kolejnych kwartałach w stosunku do analogicznego kwartału roku poprzedniego. Indeks ten osiągnął najniższy poziom w IV kwartale 2011 roku $(86,3)$, notując spadek o 10,8 pkt w stosunku do analogicznego kwartału roku poprzedniego. Natomiast najgłębszy jego spadek miał miejsce w III kwartale 2008 roku w stosunku do III kwartału 2007 roku (o 50,4 pkt), co było wynikiem gwałtownej bessy zarówno na rynku nieruchomości, jak i w całej gospodarce. Po wahaniach indeksu w latach 2010-2011 w 2012 roku można zauważyć tendencję wzrostową indeksu, którego wartość przekroczyła 100 pkt (rysunek 1). Prezentowany powyżej indeks obejmuje transakcje mieszkaniowe zawarte w granicach administracyjnych Szczecina, przy czym nie jest to badanie pełne. Należy zwrócić uwagę na fakt, że znacząca liczba transakcji odbywa się w aglomeracji miejskiej, czyli również w sąsiednich gminach bezpośrednio graniczących z miastem. 


\section{Zakres i wynik badań empirycznych}

W celu sprawdzenia, czy na wybranym rynku lokalnym indeks dla małego obszaru będzie porównywalny z indeksem dla całego rynku, wybrano jedno ze szczecińskich osiedli mieszkaniowych, na którym w badanym okresie nie realizowano nowych inwestycji, więc cały obrót odbywał się na rynku wtórnym. Badaniem pełnym objęto transakcje kupna-sprzedaży mieszkań zawarte w formie aktu notarialnego w okresie od III kwartału 2006 roku do IV kwartału 2012, dotyczące mieszkań na osiedlu Zawadzkiego-Klonowica w Szczecinie. Okres badania pozwolił na wyznaczenie indeksów w tych samych kwartałach co indeksy wyznaczone przez NBP.

Wybrane do badania osiedle ma zwarty charakter o zabudowie wielorodzinnej w wieku 25-55 lat. Wszystkie budynki na osiedlu zostały wzniesione w technologii wielkiej płyty. Osiedle to z uwagi na zainteresowanie nabywców i częstość dokonywanych transakcji, formę zabudowy, technologię wznoszenia budynków oraz strukturę mieszkań i otoczenie społeczno-gospodarcze wydaje się spełniać wymogi jednorodnego obszaru zgodnie z koncepcją Shillera. Ostatecznie zgromadzono informacje o 537 transakcjach opisanych takimi zmiennymi, jak:

- cena transakcyjna mieszkania (zł);

- powierzchnia użytkowa lokalu $\left(\mathrm{w} \mathrm{m}^{2}\right)$;

- kondygnacja budynku, na którym znajduje się lokal $(1, \ldots, 14)$;

- rodzaj nabywanego prawa (własność, spółdzielcze prawo do lokalu);

- wiek budynku (starszy - lata 60., nowszy - lata 70. i 80.);

- charakterystyka zabudowy (wysoki, niski);

- dostępność miejsc parkingowych (dobra, ograniczona);

- odległość od przystanków komunikacji miejskiej (dogodna, niedogodna).

Trzy pierwsze zmienne mierzone są na skali ilorazowej, natomiast pozostałe zmienne mają charakter jakościowy - w modelu przyjęto je jako zmienne dychotomiczne. Dostępność miejsc parkingowych opisano jako dobrą, gdy ogólnodostępne miejsca parkingowe znajdują się na wydzielonych i przyległych do budynku parkingach, a jako ograniczoną w przypadku braku parkingu bezpośrednio przy budynku. Zmienną odległość od przystanków komunikacji miejskiej MZK opisano jako dogodną w przypadku budynku znajdującego się wzdłuż ulicy, przy której jest przystanek komunikacji miejskiej. Natomiast kategoria niedogodne oznacza lokalizację wewnątrz osiedla z koniecznością dojścia do ulicy, przy której znajduje się przystanek komunikacji miejskiej. Zmienną objaśnianą w modelu był logarytm naturalny ceny transakcyjnej mieszkania sprzedawanego w obrocie wtórnym na 
lokalnym rynku, a zmiennymi objaśniającymi - cechy (atrybuty) tych mieszkań. $\mathrm{Z}$ analiz rynku wynika, że nabywcy cenią wyżej odrębną własność mieszkań niż spółdzielcze prawo do lokalu, podobnie wybierają częściej mieszkania w budynkach niskich niż wysokich.

W pierwszym etapie analizy dla badanego zbioru danych oszacowano współczynniki kwartalnych modeli regresji. Następnie odrzucono zmienne objaśniające statystycznie nieistotne. W efekcie pozostawiono zmienne: powierzchnia użytkowa lokalu, rodzaj nabywanego prawa oraz wiek budynku. W tabeli 1 zamieszczono wyniki oszacowania parametrów modelu regresji hedonicznej dla kwartału bazowego (III kwartał 2006 r.).

Tabela 1. Wyniki oszacowania parametrów modelu regresji hedonicznej dla III kwartału $2006 \operatorname{roku}\left(R^{2}=62,1 \%\right)$ wraz z wartością wskaźnika $\left(w_{j}\right)$

\begin{tabular}{|c|c|c|c|c|c|}
\hline Zmienna & $b$ & B1. std. & $t$-Stat & $p$ & $w_{j}$ \\
\hline Stała & 10,94786 & 0,126063 & 86,84405 & 0,000000 & 1,00 \\
\hline Powierzchnia użytkowa lokalu & 0,018504 & 0,002620 & 7,063035 & 0,000000 & 41,93 \\
\hline Rodzaj nabywanego prawa & 0,008349 & 0,058669 & 0,142307 & 0,000000 & 0,56 \\
\hline Wiek budynku & $-0,122410$ & 0,075420 & $-1,62299$ & 0,011950 & 0,20 \\
\hline
\end{tabular}

Źródło: obliczenia własne na podstawie danych z aktów notarialnych.

Oszacowane współczynniki regresji dla każdego kwartału były ważone wskaźnikiem $w_{j}$ będącym średnią dla zmiennej, dla której zostały oszacowane, wyznaczanej z okresu bazowego, to znaczy III kwartału 2006 roku. Szukany indeks dla kolejnego kwartału jest funkcją wykładniczą o podstawie $e$ oraz wykładniku, który jest różnicą sum dla kolejnych kwartałów, odpowiednio: analogicznych kwartałów kolejnych lat (kw/kwrub) lub kolejnych kwartałów i kwartału bazowego (kw/baz). Suma stanowi iloczyn oszacowanych współczynników modelu regresji mnożonych przez wagi $w_{j}$, gdzie $j$ to liczba zmiennych objaśniających modelu. Uzyskana wartość indeksu jest zazwyczaj mnożona przez 100 dla poprawy czytelności wyników, co również wykorzystano w obliczeniach. Na rysunku 2 przedstawiono trzy warianty indeksu cen nieruchomości lokalowych o funkcji mieszkalnej wyznaczonych dla wybranego osiedla w Szczecinie. 
Rysunek 2. Indeks hedoniczny mieszkań na rynku wtórnym w wybranej dzielnicy Szczecina w latach 2006-2012

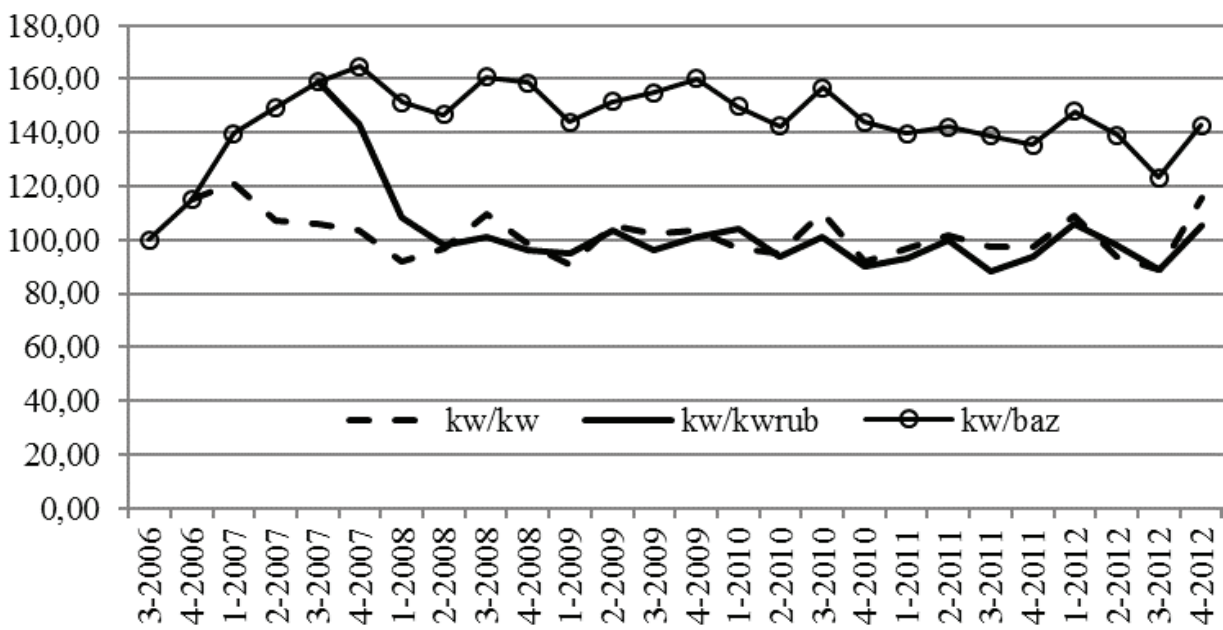

Źródło: opracowanie własne na podstawie danych z aktów notarialnych.

Indeks oznaczony symbolem kw/kw obrazuje zmiany cen w kolejnych, następujących po sobie kwartałach, natomiast kw/baz - zmiany cen w kolejnych kwartałach w stosunku do kwartału bazowego (III kwartał 2006 r.). Z wyjątkiem pierwszych 8 analizowanych kwartałów przebieg obu linii jest podobny, wskazując jednocześnie na pogarszanie się kondycji lokalnego rynku oraz nieustabilizowaną sytuację. Potwierdzają to coraz większe wahania indeksów, począwszy od 2011 roku.

Na poparcie hipotezy, iż indeksy cen wyznaczane dla małych obszarów różnią się w przebiegu od indeksów dla większych zagregowanych obszarów, porównano indeks mieszkaniowy wyznaczony przez NBP dla Szczecina (rysunek 1) z indeksem cen dla badanego obszaru (rysunek 2) w ujęciu kwartał do analogicznego kwartału roku poprzedniego (rysunek 3).

Analizując uzyskane wyniki, można zauważyć podobny kierunek przebiegu obu wyznaczonych wskaźników z gwałtownym spadkiem w latach 2007-2008, wahania wokół 100 pkt w latach 2009-2010, obniżenie wartości w 2011 roku poniżej 100 pkt oraz tendencję wzrostową w 2012 roku. Jednak poza dwoma ostatnimi kwartałami 2008 roku amplituda wahań obu wskaźników jest różna. Okresowo zdarzają się wartości wskaźników świadczące o przeciwnych kierunkach zmian cen na badanym osiedlu w stosunku do całego miasta. Wskaźniki wyznaczone dla danego osiedla zanotowały częściej większe wahania niż wskaźniki dla całego miasta. Największa 
rozbieżność obu wskaźników miała miejsce w II kwartale 2008 roku, co mogło wynikać z pierwszych symptomów pogarszającej się koniunktury na rynku mieszkaniowym dostrzeganej szybciej na lokalnym rynku niż w całym mieście.

Rysunek 3. Indeks hedoniczny mieszkań na rynku wtórnym w wybranej dzielnicy Szczecina oraz dla miasta Szczecina w latach 2007-2012

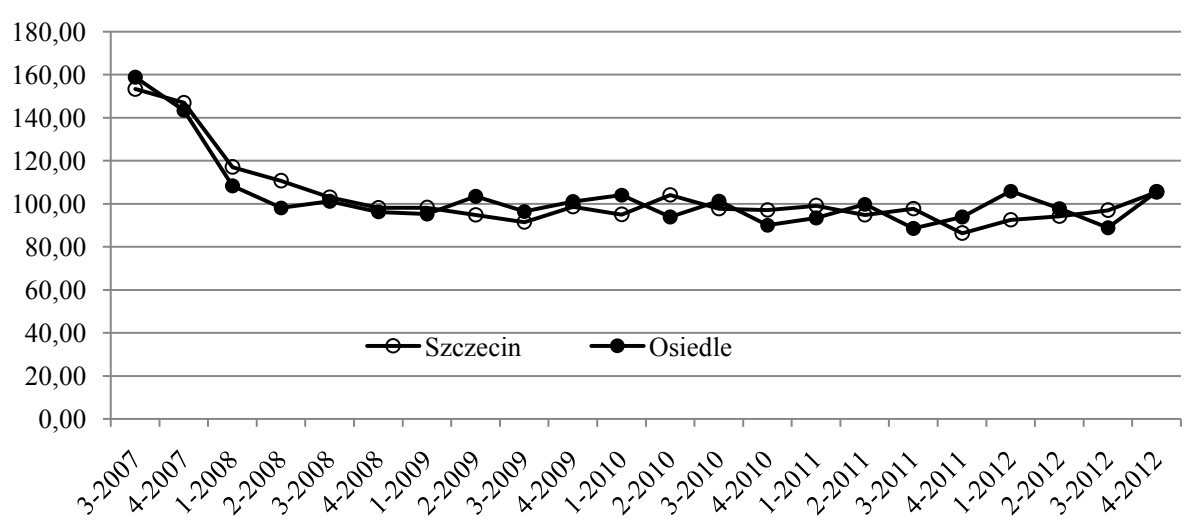

Źródło: opracowanie własne na podstawie danych z aktów notarialnych oraz NBP.

\section{Podsumowanie}

Rzadkość zawieranych umów kupna-sprzedaży nieruchomości w porównaniu do innych dóbr przy niejednorodności przedmiotów umów powoduje, że koncepcja podziału zbiorowości na jednorodne grupy jest barierą wykorzystania klasycznych metod wyznaczania indeksów cen i powoduje, że każda z proponowanych w literaturze metoda jest niedoskonała. Na tym tle koncepcja Shillera podziału obszaru, dla którego wyznacza się indeksy cen, na jednorodne zbiory pod względem otoczenia rynku nieruchomości jest nowym kierunkiem w teorii indeksów cen nieruchomości pozwalającym na lepsze dopasowanie wyznaczanych indeksów do rzeczywistych zmian zachodzących na lokalnych rynkach nieruchomości. W przypadku, gdy na jednorodnych obszarach jest zbyt mało transakcji, należy poszerzać rynek i łączyć małe obszary w większe skupiska. Następnie po wyznaczeniu indeksów dla tych nowych rynków lokalnych należy wskaźniki zagregowane konstruować dla rynku większego, na przykład dla miasta, aglomeracji miejskiej, województwa lub regionu. 
W prezentowanym badaniu przeprowadzano analizę jednorodnego lokalnego rynku mieszkaniowego w celu wyznaczenia indeksów cen mieszkań w obrocie wtórnym. Uzyskane indeksy zestawiono z indeksem hedonicznym wyznaczanym przez NBP dla największych miast Polski, w tym również dla Szczecina. Uzyskane wyniki okazały się zbliżone co do głównej tendencji zmian cen. Jednak bliższa ich analiza wskazuje na różne amplitudy zmian oraz zdarzające się krótkotrwałe tendencje przeciwne w zmianie wartości obu wskaźników. Ostateczne wnioski nie są jednak możliwe bez porównania udziału transakcji z danego osiedla w transakcjach branych od uwagę do konstruowania wskaźnika NBP dla całego miasta. Kontynuacja badań dla kolejnych jednorodnych małych obszarów na terenie Szczecina i agregacja uzyskanych wyników dla całego miasta pozwoli w pełni zweryfikować konieczność stosowania takiego podejścia do konstruowania indeksów cen mieszkań, a w konsekwencji również dla pozostałych rodzajów nieruchomości.

\section{Literatura}

Batóg, B., Foryś, I. (2013). Modele cen nieruchomości mieszkaniowych na rynku lokalnym. W: B. Pawełek (red.), Zastosowanie metod ilościowych w modelowaniu i prognozowaniu zjawisk społeczno-gospodarczych (s. 220-234). Kraków: Wyd. UE w Krakowie.

Bourassa, S.C., Hoesli, M., Sun, J. (2006). A Simple Alternative House Price Index Method. Journal of Housing Economics, 15, 1, 80-97.

Calhoum, Ch.A. (1996). OFHEO House Price Indexes: HPI Technical Description. Washington: Office of OFHEO.

Fleming, M.C., Nellis, J.G. (1994). The Measurement of UK House Process. Review and Appraisal of Principal Sources. Journal of Housing Finance, 24, 6-16.

Foryś, I. (2010). Wykorzystanie metod taksonomicznych do wyboru obiektów podobnych w procesie szacowania lokali mieszkalnych. Studia i Materiaty TNN, 18, 1, 95-106.

Foryś, I. (2012). Metoda mix-adjustment wyznaczania indeksów cen nieruchomości mieszkaniowych na przykładzie lokali spółdzielczych. Studia i Materiały Towarzystwa Naukowego Nieruchomości, 20, 1, 41-52.

Foryś, I. (2013). Wykorzystanie indeksów cen mieszkań do oceny zwrotu z inwestycji bezpośrednich na przykładzie wybranego rynku lokalnego. Zeszyt Naukowy Uniwersytetu Szczecińskiego, 768, Finanse, Rynki Finansowe, Ubezpieczenia, 63, 109-126.

Handbook on Residential Property Prices Indices (RPPIs) (2013). Economy and Finance, Methodologies \& Working Papers, Eurostat, United Nations Economic Commission for Europe.

Łaszek, J., Widłak, M. (2008). Badanie cen na rynku mieszkań prywatnych zamieszkałych przez właściciela z perspektywy banku centralnego. Bank $i$ Kredyt, 39, 8, 12-41. 
Meese, R., Wallace, N. (1997). The Construction of Residential Housing Price Indices: a Comparison of Repeat Sales, Hedonic Regression, and Hybrid Approaches. Journal of Real Estate Finance and Economics, 14, 1/2, 51-74.

Trojanek, R. (2010). Porównanie metod prostych oraz metody regresji hedonicznej do konstruowania indeksów cen mieszkań. Studia i Materiaty TNN, 18, 1, 119-132.

Shiller, R.J. 1991. Arithmetic Repeat Sales Price Estimators. Journal of Housing Economics, 1, 110-126.

Ustawa z 21.08.1997 o gospodarce nieruchomościami. Dz.U. 2015, poz. 782, z późn. zm.

Widłak, M. (2010). Metody wyznaczania hedonicznych indeksów cen jako sposób kontroli zmian jakości dóbr. Wiadomości Statystyczne, 9, 1-25.

Wood, R. (2005). A Comparison of UK Residential House Price Indices. BIS Paper, 21, 212-227.

www.nbp.pl/publikacje/rynek_nieruchomosci/ceny_mieszkan.xls (2.09.2015).

www.spindices.com/index-family/real-estate/sp-case-shiller (2.09.2015).

\title{
REAL ESTATE PRICE INDICES FOR SMALL AREA
}

\begin{abstract}
The article deals with the subject of creating housing price indices, taking into account the Robert Shiller concept. He indicates a problem of homogeneity of the data used for the construction of price indices. An overview of methods and experiences was conducted for selected countries that construct indices of housing price, including the UE market. Against this background, the actions undertaken in Poland were evaluated. On the example of the local market and the defined typical house, a hypothesis on the quality of the housing price index in the local market and the regional index was verified.
\end{abstract}

Translated by Iwona Foryś

Keywords: property valuation, apartments price index, real estate market

JEL Code: R15 